\title{
Celah Hukum Spionase: Cukup dengan Hukum Kebiasaan atau Tata Cara Perang Perlu Pembaharuan?
}

\author{
Edson Septo Yosia*; Dony Yusra Pebrianto; Mochammad Farisi \\ Fakultas Hukum Universitas Jambi \\ *Corresponding author: edsonsepto@gmail.com \\ Submission : 16 Juni 2021 \\ Revision : 24 September 2021 \\ Publication : 12 Oktober 2021
}

\begin{abstract}
At first, war was only carried out by the disputing parties but as the times progressed, the war also had an impact on the surrounding area or other countries. Arrangements for war need to be made such as war treaties or procedures. One of the unclear regulations concerning the act of espionage or what is known as spying. International humanitarian law regulates the customs of war and the manner of war. It turns out that the convention does not clearly regulate the legal protection of spy agencies. This article tries to discuss the urgency of protecting spy agents who are serving in war under humanitarian law
\end{abstract}

Keywords: protection; spy agency; war; international humanitarian law.

\begin{abstract}
Abstrak
Pada mulanya, perang hanya dilakukan oleh pihak-pihak yang bersengketa, namun semakin berkembangnya zaman perang juga berdampak ke wilayah sekitar atau negara lainnya. Pengaturan demi pengaturan akan peperangan perlu dibuat seperti perjanjian perang ataupun tata caranya. Salah satu ketidakjelasan pengaturannya yaitu menyangkut tindakan spionase atau yang dikenal dengan istilah matamata. Hukum Humaniter Internasional mengatur mengenai kebiasaan
\end{abstract}


perang dan tata cara perang. Ternyata konvensi tersebut tidak mengatur secara jelas mengenai perlindungan hukum terhadap agen mata-mata. Artikel ini mencoba membahas urgensi perlindungan agen mata-mata yang sedang bertugas dalam perang menurut hukum humaniter internasional.

Kata Kunci: perlindungan; agen mata-mata; perang; hukum humaniter internasional.

\section{A. Pendahuluan}

Peperangan adalah suatu alat agar kepentingan tiap-tiap negara terpenuhi. Dengan adanya kepentingan-kepentingan tersebut, maka perang merupakan suatu tindakan yang legal sebagai salah satu cara untuk menyelesaikan pertikaian antarnegara. ${ }^{1}$ Sejarah manusia hampir tidak pernah bebas dari peperangan. ${ }^{2}$ Dalam peradabannya, manusia dan peperangan adalah dua kata yang sulit dipisahkan yang selalu menghiasi di setiap waktu.

Dalam peperangan itu sendiri, manusia selalu menggunakan begitu banyak strategi perang demi tercapainya kemenangan yang dibanggakan, dan tentu saja demi mencapai kepentingan kelompok atau bahkan negara tertentu. Pada mulanya perang seperti itu hanya dilakukan oleh pihak-pihak yang bersengketa. Semakin berkembangnya zaman, perang juga berdampak pada wilayah sekitar atau negara lainnya. Akhirnya negara-negara di dunia bersepakat membentuk

1 A.K Syahmin. Hukum Internasional Humaniter. Bandung. Armico. 1985. hal. 19.

${ }^{2}$ Ibid. hal. 5.

Uti Possidetis: Journal of International Law, Vol. 2, No. 3 (2021) 
Edson Septo Yosia, Dony Yusra Pebrianto \& Mochammad Farisi

Perserikatan Bangsa-Bangsa sebagai penengah dalam kehidupan bernegara di dunia internasional. Perjanjian perang terus diperbaharui, namun beberapa aturan masih dirasa tidak ada kejelasan, salah satunya tentang spionase. ${ }^{3}$

Spionase merupakan suatu tindakan yang sering digunakan dalam perang sebagai suatu strategi dalam perang untuk memenangkan peperangan. Seorang ahli strategi perang dari China, Sun Tzu menjelaskan betapa besar pentingnya strategi seperti ini. Kemenangan tertinggi adalah memenangkan perang tanpa adanya suatu pertempuran. ${ }^{4}$ Penggunaan mata-mata ini sudah lama digunakan dan dianggap suatu kebiasaan dalam perang.

Penggunaan tipu daya atau muslihat memang dianggap lumrah oleh seorang panglima strategi perang seperti Machiavelli. ${ }^{5}$ Di tangan Machiavelli, pandangan perbedaan klasik antara kawan dan lawan menjadi kabur, karena setiap kawan adalah musuh yang potensial, maka orang tidak lagi

${ }^{3}$ Rampengan D Febriyanto. Status Perlindungan Hukum Agen Mata-Mata Ditinjau Dari Perspektif Hukum Humaniter Internasional. Jurnal Ilmu Hukum. Vol. 5. No 10. hal. 131.

${ }^{4}$ Atmadja Nugraha Purna. Dukungan Indonesia Terhadap Resolusi Anti Spionase Perserikatan Bangsa-Bangsa. Jurnal Hubungan Internasional. 2017. hal. 935.

${ }^{5}$ Niccolo Machiavelli. The Art Of War. Diterjemahkan oleh Alkhatab dan Setiawan. 2015. hal. Lxvi. 
terlalu enggan menggunakan tipu daya dan kekerasan dengan sesamanya. 6 Sekarang yang menjadi permasalahan adalah pengaturan yang cukup jelas mengenai mata-mata itu sendiri atau kejelasan mengenai status dirinya. Status spionase itu sendiri tidak jelas, apakah ia seorang kombatan atau penduduk sipil. Akibat Konvensi Den Haag mengakui adanya tindakan spionase atau kegiatan memata-matai, maka sejatinya matamata masuk ke dalam komponen perang.

Dalam Protokol-Protokol Tambahan I Tahun 1977, matamata dianggap sebagai suatu kesalahan dan tidak dibenarkan praktiknya dalam peperangan. Penggunaan mata-mata atau spionase tetap saja ada dan bahkan dianggap lumrah, yang sangat disayangkan adalah bagaimana bahwa mata-mata atau spionase, status mereka akan menjadi berbeda saat ditawan dalam peperangan. Mereka tidak mendapat hak-hak sebagai tawanan perang. Melainkan sebagai mata-mata atau dianggap penjahat perang.

Mata-mata adalah sesuatu yang dilakukan diam-diam untuk mendapatkan intelijensi yang bersifat sensitif yang biasanya, menyangkut tentang informasi kemiliteran sebuah negara atau pasukan. ${ }^{7}$ Terdapat beberapa Pasal yang terasa

${ }^{6}$ Ibid. hal. Lxvii.

7 Nen Yunani Rhenaldo.Tindakan Spionase Yang Dilakukan Negara Amerika Serikat Terhadap Kepala Negara Perancis Ditinjau Dari Hukum Diplomatik. Jurnal Hukum Hubungan Internasional. 2016. hal. 4 .

Uti Possidetis: Journal of International Law, Vol. 2, No. 3 (2021) 
Edson Septo Yosia, Dony Yusra Pebrianto \& Mochammad Farisi

saling kontradiksi mengenai penggunaan spionase dan aturannya.

Di dalam Pasal 24 Konvensi Den Haag mengatakan tipu daya perang dan penggunaan cara-cara yang diperlukan untuk memperoleh informasi mengenai musuh dan negaranya diperbolehkan. Pasal 25 Konvensi Den Haag mengatakan penyerangan atau pemboman dengan alat apapun terhadap kota-kota, kampung-kampung, pemukiman atau bangunanbangunan yang tidak dipertahankan dilarang. Berdasarkan Pasal 29 Konvensi Den Haag, seseorang hanya dapat dianggap sebagai mata-mata apabila melakukan suatu perbuatan secara diam-diam atau berpura-pura untuk mencari dan memperoleh informasi di daerah operasi dari negera-negara yang berperang dengan maksud untuk memberitahukannya kepada pihak musuh.

Sejatinya penggunaan mata-mata atau spionase diperbolehkan, karena dalam peperangan spionase dianggap sebagai strategi penipuan atau daya muslihat dalam mengumpulkan intelijensi, bahkan jika dilanjut pada Pasal 25 bahwa dilarang menyerang atau mem-bom wilayah atau bangunan yang tidak dipertahankan adalah salah satu tujuan spionase dalam mengumpulkan informasi. Informasi ini 
bertujuan mengetahui wilayah-wilayah yang tidak bisa diserang, sehingga tidak ada salah target dalam penyerangan. ${ }^{8}$

Pemahaman kesederajatan dan perlindungan hak atas tawanan perang, merumuskan status spionase dalam Hukum Internasional menjadi salah satu topik yang harus dibawa, bila dilihat pada Pasal 4 ayat (3) International Covenant on Civil And Political Rights yang menyatakan bahwa HAM bersifat nonderogable rights yaitu HAM yang tidak dapat ditunda pelaksanaannya dalam situasi apapun baik perang maupun damai yang lazim disebut hak-hak pokok. Atas dasar HAM permasalahan mengenai status spionase dalam peperangan dan pengaturan akan dirinya yang masih tidak jelas dan penerapannya jauh dari yang diharapkan dapat untuk diteliti lebih jauh.

\section{B. Pembahasan Dan Analisis}

1. Status Agen Mata-Mata Dalam Melakukan Tindakan Spionase Dalam Perang Menurut Hukum Humaniter Internasional.

Penjelasan mengenai status seorang agen mata-mata sudah dijelaskan dalam beberapa uraian bab di atas, namun artikel ini menginginkan penjelasan yang berada di Konvensi untuk menambahkan seorang Intelijen agen mata-mata masuk sebagai salah satu komponen kombatan. Walaupun demikian,

\footnotetext{
${ }^{8}$ Febriyanto. Op. Cit. hal.130.
}

Uti Possidetis: Journal of International Law, Vol. 2, No. 3 (2021) 
Edson Septo Yosia, Dony Yusra Pebrianto \& Mochammad Farisi

ada beberapa unsur yang menjadi alasan mengapa seorang Agen Intelijen seperti agen mata-mata harus masuk kedalam kategori kombatan.

Di dalam konvensi tersebut, agen mata-mata terdapat dalam beberapa pasal, seperti Pasal 29 Konvensi Den Haag mengatakan bahwa seseorang hanya dapat dianggap sebagai mata-mata, apabila melakukan suatu perbuatan secara diamdiam atau berpura-pura untuk mencari dan memperoleh informasi di daerah operasi dari negara-negara yang berperang dengan maksud untuk memberitahukannya kepada musuh. Tentara yang tidak dalam penyamaran yang telah menerobos masuk ke daerah operasi pihak musuh untuk memperoleh informasi, tidak dianggap sebagai mata-mata. Demikian pula, golongan berikut tidak dianggap sebagai mata-mata yaitu tentara atau orang sipil yang melaksanakan misinya secara terbuka, yang bertugas menyerahkan berita, baik kepada pasukannya sendiri atau pun kepada musuhnya. Dalam pengertian ini termasuk juga orang-orang yang dikirimkan dengan menggunakan balon untuk menyampaikan berita dan biasanya untuk memelihara komunikasi diantara satuansatuan yang berbeda dari suatu pasukan wilayah.

Dalam Pasal 30 Konvensi Den Haag mengatakan bahwa seorang mata-mata yang tertangkap ketika sedang menjalankan tugas atau melaksanakan pekerjaannya tidak 
dapat dihukum tanpa melalui proses pengadilan sebelumnya. Dalam Pasal 31 Konvensi Den Haag, seorang mata-mata yang telah bergabung kembali dengan pasukannya kemudian tertangkap oleh musuh, diperlakukan sebagai penjahat perang, dan tidak dibebani tanggung jawab atas tindakan mata-mata yang dilakukan sebelumnya.

Pada dua pasal konvensi di atas dapat disimpulkan, bahwa seorang agen mata-mata tidak akan di hukum tanpa adanya proses pengadilan dan apabila tertangkap setelah menjalani tugasnya sebagai mata-mata namun telah kembali pada pasukannya, maka tidak dibebani atas tindakan sebelumnya.

Dalam Konvensi Jenewa pada Protokol Tambahan I Tahun 1977 juga dibahas mengenai perlakuan terhadap matamata seperti disebutkan pada beberapa Pasal seperti Pasal 46 Protokol-Protokol Tambahan Jenewa Tahun 1977. Dalam kedua Konvensi Den Haag dan Konvensi Jenewa dengan jelas menyebutkan bahwa, seseorang dapat mengumpulkan informasi atau berusaha mengumpulkan keteranganketerangan bernilai militer selama dalam melaksanakannya, memakai seragam angkatannya. Tidak melakukan secara diamdiam, apabila ia tertangkap setelah kembali pada pasukan dimana ia menjadi anggotanya, maka haknya dalam status tawanan perang tidak lah hilang.

Dalam Kovensi Den Haag Pasal 29 disebutkan bahwa anggota angkatan perang atau pun penduduk sipil bilamana 
Edson Septo Yosia, Dony Yusra Pebrianto \& Mochammad Farisi

melakukan pengumpulan keterangan yang dianggap rahasia, atau keterangan-keterangan militer tidak ditangkap bila telah kembali ke kesatuan pasukannya. Dengan begitu penduduk sipil yang dikepalai oleh suatu lembaga dan mempunyai misi dalam suatu sengketa peperangan menjadi perangkat perang itu sendiri.

\section{Perlindungan Hukum Agen Mata-Mata Dalam}

\section{Perang}

Konvensi Jenewa 1949 yang mengatur mengenai perlindungan korban perang dalam Protokol Tambahan I Tahun 1977 dalam Pasal 46 tidak diatur secara jelas, mengenai perlindungan yang dimiliki oleh agen mata-mata dan hanya menjelaskan akan dianggap sebagai mata-mata apabila tertangkap oleh pihak musuh dalam melaksanakan tugasnya dan tidak mendapatkan hak sebagai Tawanan Perang seperti kombatan atau anggota angkatan perang lainnya.

Menurut Pasal 46, seorang angkatan bersenjata dapat melakukan kegiatan mata-mata selama ia melakukannya secara terang-terangan atau terbuka atau menggunakan seragam nya pada waktu ia menjalankan misi memata-matai. Sekarang yang menjadi persoalan adalah konsekuensi bila ia tidak menggunakan seragam dan apabila ia tertangkap, maka ia akan 
dipelakukan sebagai seorang mata-mata dan haknya sebagai tawanan perang akan hilang.

Hal ini mengakibatkan seseorang yang kedapatan melakukan kegiatan mata-mata secara diam-diam atau tipu muslihat akan dihukum layaknya seseorang yang melakukan kejahatan. Dirinya tidak akan mendapat status tawanan perang sesuai dengan Konvensi Jenewa III. ${ }^{9}$

Indonesia telah mengatur hukuman yang akan diberikan kepada mata-mata yang terbukti melakukan kegiatan matamata terhadap negara Indonesia. Terdapat beberapa Pasal Kitab Hukum Undang-undang Pidana (KUHP) seperti Pasal 112, 113, dan 114 yang telah menjelaskan secara rinci tindakan serta hukuman bila kedapatan melakukannya. Sebaliknya, apabila anggota bersenjata melakukan kegiatan mata-mata dengan mengenakan seragam, maka ia apabila tertangkap musuh, ia tetap diperlakukan sebagai tawanan perang dan memperoleh hak-haknya sesuai Konvensi Jenewa III. Demikian pula bila ia berdiam di wilayah yang diduduki musuh, maka apabila ia tidak melakukan kegiatan mata-mata dan tiba tertangkap oleh musuh, ia tetap menerima dan berhak akan status nya sebagai seorang tawanan perang.

Bila seorang melakukan kegiatan mata-mata di daerah, di luar wilayah kekuasaan yang diduduki musuh dan berdiam disana ia tetap mendapatkan haknya sebagai seorang tawanan

${ }^{9}$ Arlina Permansari, et. al, Pengantar Hukum Humaniter. hal. 95.

Uti Possidetis: Journal of International Law, Vol. 2, No. 3 (2021) 
Edson Septo Yosia, Dony Yusra Pebrianto \& Mochammad Farisi

perang apabila dalam menjalankan kegiatan mata-mata tersebut ia tidak tertangkap dan telah kembali ke kesatuannya. Berdasarkan penjelasan di atas yang tertuang dalam Konvensi, tidaklah mungkin seorang yang dimana sedang dalam masa perang dengan terang-terangan menggunakan seragam dari negara oposisi untuk melakukan kegiatan memata-matai pihak oposisi. Sebenarnya bisa saja hal itu dilakukan namun itupun dari kejauhan dan lebih kepada pengintaian yang tidak semaksimal melakukan kegiatan mata-mata.

Berdasarkan Konvensi Jenewa dalam Protokol Tambahan I, menyatakan apabila seorang angkatan bersenjata terbukti melakukan kegiatan mata-mata, dia tidak berhak atas status sebagai tawanan perang. Tidak dapat menjamin, bahwa seorang mata-mata apabila jatuh dalam kekuasaan musuh akan diperlakukan secara manusiawi, karena orang tersebut tidak memiliki status sebagai tawanan perang seperti yang dijabarkan dalam Pasal 46 Protokol Tambahan I, ia tidak akan memperoleh manfaat dari perlindungan-perlindungan yang diberikan oleh status tersebut sehingga harus bertanggung jawab secara hukum atas tuntutan dibawah hukum kriminal normal.

Dalam Pasal 45 ayat (3) dan Pasal 75 Protokol Tambahan I telah mengatur mengenai jaminan-jaminan dasar yang harus diberikan pada orang yang tertawan di pihak musuh, akan 
tetapi ini hanya berlaku kepada orang yang tidak tergolong dalam Pasal 43 dan Pasal 44 Protokol Tambahan I dan orangorang tersebut adalah warga sipil yang bukan bagian dari peserta perang. Dalam Konvensi Jenewa III 1949 telah memberikan definisi mengenai tawanan perang, seorang yang berstatus sebagai Kombatan, otomatis akan mendapatkan perlakuan sebagai tawanan perang, apabila mereka dalam kondisi hors de combat dan jatuh ke tangan musuh.

Ada pula sekelompok penduduk sipil tertentu, walaupun mereka bukan kombatan, apabila jatuh ke tangan musuh mereka tetap diberikan status sebagai tawanan perang. Hal ini diatur dalam Pasal 4 Konvensi Jenewa III, yang menetapkan syarat-syarat bagi seorang yang berhak atas status sebagai tawanan perang, di samping itu Pasal 4 ini sangat penting karena dianggap juga sebagai perincian status peserta orang.

Berdasarkan penjelasan di atas dapat disimpulkan bahwa mata-mata juga bisa tergolong ke dalam syarat peserta perang. Dengan beberapa ciri yang sama seperti kegiatan mata-mata dilakukan oleh angkatan bersenjata pihak yang berkonflik, dan mendapat perintah dari atasannya yang bertanggung jawab atas bawahan-bawahannya, seperti yang dijabarkan mengenai mata-mata dalam Protokol Tambahan I Pasal 46 dan melakukan operasi sesuai dengan hukum dan kebiasaan perang, berdasarkan Pasal 24 Konvensi Den Haag IV serta pengaturan nya pada Pasal 29 Konvensi Den Haag VI dan menyatakan suatu 
Edson Septo Yosia, Dony Yusra Pebrianto \& Mochammad Farisi

kesetiaannya pada suatu pemerintahan atau negara seperti yang diatur pada ayat (3) Pasal 4 Konvensi Jenewa III.

Tidak adanya pemberian status tawanan perang pada agen intelijen atau agen mata-mata akan menimbulkan celah, yang merugikan Hak Asasi Manusia yang dimiliki oleh setiap manusia, termasuk manusia yang menjadi seorang agen intelijen atau agen mata-mata. Masalah selanjutnya adalah sekalipun seorang agen intelijen atau agen mata-mata mendapatkan perlindungan apabila ia jatuh ke dalam kekuasaan musuh, dia akan tetap diadili sebagai seseorang yang melakukan kejahatan, dan bisa saja dituntut hukuman mati, seperti hukuman yang berlaku di Indonesia apabila ia kedapatan dan terbukti melakukan tindakan mata-mata. ${ }^{10}$

Dalam Hukum Hak Asasi Manusia pada Pasal 4 ayat (3) International Covenant on Civil and Political Rights menyatakan bahwa HAM bersifat non-derogable rights (HAM yang tidak dapat ditunda pelaksanaanya dalam situasi apapun). Hak hak pokok yang lazim disebutkan meliputi: Hak untuk hidup (Pasal 6); hakk untuk tidak dipaksa (Pasal 7); Hak untuk tidak diperbudak dan diperhamba (Pasal 8); Hak untuk tidak dipenjara semata-mata atas dasar ketidakmampuan untuk memenuhi suatu kewajiban kontrak (Pasal 11); Hak untuk

${ }^{10}$ Febriyanto. Op. Cit. hal.136

Uti Possidetis: Journal of International Law, Vol. 2, No. 3 (2021) 
dinyatakan berdasarkan aturan yang berlaku surut (Pasal 15); Hak untuk diakui dimanapun sebagai manusia di hadapan hukum (Pasal 16); Hak untuk bebas berpikir, berkeyakinan dan beragama (Pasal 18). ${ }^{11}$

Begitupun Kovensi Den Haag IV pada Pasal 29, telah mengatur penggunaannya. Secara tidak langsung telah mengijinkan adanya tindakan atau operasi mata-mata. Lantas kegiatan mata-mata yang sudah diatur dan sudah lazim penggunaannya, bagaimana mungkin tidak adanya perlindungan hukum untuk menjaganya sebagai manusia yang aktif kedalam medan perang demi terpenuhinya hak-haknya sebagai manusia.

Memberikan agen intelijen atau agen mata-mata bukanlah suatu komponen kombatan telah keliru, mengingat pengaturannya sudah diatur dalam konvensi yang menjadi alat dan masuk kedalam tata cara berperang yang sudah menjadi panduan. Penggunaan pengumpulan informasi oleh agen intelijen atau agen mata-mata sudah termasuk ke dalam patokan kebiasaan dalam perang dan juga diakui keberadaannya oleh Konvensi Jenewa yang mengatur perlindungan terhadap peserta atau anggota dari perang atau korban perang dalam Protokol Tambahan I pada Pasal 46.

${ }^{11}$ Ibid.

Uti Possidetis: Journal of International Law, Vol. 2, No. 3 (2021) 
Edson Septo Yosia, Dony Yusra Pebrianto \& Mochammad Farisi

Maka dalam hal ini pemberian status perlindungan agen mata-mata dalam perang seperti seorang angkatan bersenjata yang melakukan misi penetrasi ke dalam pihak oposisi atau lawan diberikan status perlindungan sebagai tawanan perang sehingga, tidak melukai dan terjaminnya Hak Asasi Manusia nya sebagai seorang manusia. Meskipun telah banyak dibentuk didalam Konvensi-Konvensi menyatakan segala yang mencakup di dalamnya harus dilindungi saja masih sulit penerapan dalam peritiwa aslinya apalagi bila tidak ada aturan yang tertulis di dalammnya yang dapat menimbulkan celah yang meloloskan suatu pelanggaran.

\section{Penutup}

Keberadaan seorang agen intelijen atau agen mata-mata, yang dilandaskan pada kebiasaan dalam perang, yang diatur dalam Konvensi Den Haag, membuat pengaturan terhadap kegiatan memata-matai diatur dalam Pasal 29 Kovensi Den Haag IV dan Pasal 46 Protokol Tambahan I 1977, sebagai alat untuk mendapatkan suatu informasi yang bersifat rahasia, yang dapat menguntungkan pihak yang memata-matai. Agar mencapai kemenangan yang didambakan atau bahkan kemenangan tanpa peperangan. Namun pada akhirnya terdapat celah hukum, yang dimana seorang agen mata-mata atau agen intelijen tidak mendapat perlindungan ketika sedang 
melakukan aksi mencari sekumpulan informasi rahasia lawan, dimana tidak termuat dengan jelas, yang dapat menimbulkan pelanggaran-pelanggaran di dalamnya. Oleh karena itu perlu adanya perlindungan dalam perang secara jelas seperti tawanan perang, dan memasukkan agen mata-mata sebagai suatu kombatan dalam pertikaian perang.

\section{Referensi}

\section{Instrumen Hukum}

Konvensi Den Haag 1907 Hukum Dan Kebiasaan Perang Di Darat.

Konvensi Jenewa 1949 Tentang Perbaikan Keadaan Anggota Angkatan Perang Yang Luka Dan Sakit Di Medan Pertempuran Darat.

Protokol Tambahan Pada Konvensi Jenewa 12 Agustus 1949 Dan Yang Berhubungan Dengan Perlindungan KorbanKorban Pertikaian-Pertikaian Bersenjata Internasional (Protokol Tambahan I).

\section{Buku}

Machiavelli, Niccolo. The Art of War. Cetakan ke-1. Terjemahan

E. Setiyawati dan Toni Setiawan. Yogyakarta. Narasi. 2019. Permanasari Arlina. et. al. Pengantar Hukum Humaniter Internasional. Internasional Committee of The Red Cross. Jakarta. 1999.

Syahmin, A.K. Hukum Internasional Humaniter Jilid 1 Bagian Umum. Bandung. CV Armico. 1985.

\section{Artikel/Jurnal/Karya Ilmiah}

Anggreni, Ida Ayu Kade Ngurah, et. al. "Analisis Yuridis Pertanggungjawaban Pemimpin Negara Terkait Dengan 
Edson Septo Yosia, Dony Yusra Pebrianto \& Mochammad Farisi

Kejahatan Perang Dan Upaya Mengadili Oleh Mahkamah Pidana Internasional (Studi Kasus Omar Al-Bashir Presiden Sudan)". Jurnal Ilmu Hukum. Vol. 2 No.1. 2019. Atmadja, Nugraha Purna. "Dukungan Indonesia Terhadap Resolusi Anti Spionase Perserikatan Bangsa-Bangsa". Jurnal Hubungan Internasional. 2017.

Febriyanto, Rampengan D. "Status Perlindungan Hukum Agen Mata-Mata Ditinjau Dari Perspektif Hukum Humaniter Internasional". Jurnal Ilmu Hukum. Vol. 5 No. 10. 2017.

Nen Yunani Rhenaldo. Tindakan Spionase Yang Dilakukan Negara Amerika Serikat Terhadap Kepala Negara Perancis Ditinjau Dari Hukum Diplomatik. Jurnal Hukum Hubungan Internasional. 2016.

\section{Website}

Pratama, Aswab Nanda. Aksi Agen Spionase. Kompas. Artikel. 2019. https://internasional.kompas.com/read/2019/02/ 13/18221021/aksi. Diakses pada tanggal 13 Februari 2019. 